\title{
Effects of rapeseed oil duodenal infusion on adipose tissue lipolytic activities of dairy cows during early lactation
}

\author{
G Gagliostro1,2, Y Chilliard1 \\ with the technical assistance of $\mathrm{J}$ Fléchet, $\mathrm{J}$ Lefaivre \\ 'Laboratoire de la Lactation, INRA, Theix, 63122 Ceyrat, France; \\ 2 INTA, Balcarce, Argentina
}

The aim of this study was to evaluate the effects of rapeseed oil duodenal infusion in early lactating dairy cows that are mobilizing their body lipids. Experimental cows and nutritional treatments were described by Chilliard et al (1990). On the 21st ( \pm 1 ) d of lactation, perirenal and subcutaneous (S) adipose tissue samples were biopsied, and lipolytic activities measured as described by Gagliostro and Chilliard (1988).

Neither perirenal $(P)$ nor $S$ adipose tissue glycerol or free fatty acid (FFA) releases were significantly affected by oil treatment (O) (table I). Values tended, however, to be higher in the control (C) group, in accordance with the higher preprandial plasma FFA levels in vivo $(1,42$ $\mathrm{mM}$ in $\mathrm{C}$ and $1,04 \mathrm{mM}$ in $0 ; P<0.1$ ). There were no differences in stimulated glycerol release between the 2 anatomic sites. In group $O$, stimulated FFA release was higher $(P<0.1)$ from $S$ than from $P$ adipose tissue, without changes in the
FFA/glycerol ratio. The basal FFA/glycerol ratio tended to be higher in group $O$ in both tissues (table I). However, the activity of perirenal 3-glycerol- $P$ dehydrogenase, an enzyme involved in (re)esterification of FFA, was the same in both groups. Basal glycerol release, and the FFA/glycerol ratio, tended to be respectively lower and higher in $S$ than in $P$. These results probably reflect partial hydrolysis of triglycerides and a higher turnover rate of FFA.

The trend towards lowered lipolytic activities with $O$ is in accordance with the lower milk yield and the higher calculated energy balance of these cows, but not with changes in empty body weight and $S$ adipose cell size (Chilliard et al, 1990).

Chilliard Y, Gagliostro G, Ollier A, Bauchart D (1990) Reprod Nutr Dev suppl 2, 229s

Gagliostro G, Chilliard Y (1988) Reprod Nutr Dév 28 (suppl 1), 175-176

Table I.

\begin{tabular}{|c|c|c|c|c|c|c|c|c|c|c|c|c|}
\hline & \multicolumn{6}{|c|}{ Perirenal ${ }^{\prime}$} & \multicolumn{6}{|c|}{ Subcutaneous ${ }^{1}$} \\
\hline & \multicolumn{2}{|c|}{ glycerol } & \multicolumn{2}{|r|}{$F F A$} & \multicolumn{2}{|c|}{ FFA'glycerol } & \multicolumn{2}{|c|}{ glycerol } & \multicolumn{2}{|c|}{$F F A$} & \multicolumn{2}{|c|}{ FFA/glycerol } \\
\hline & $c$ & 0 & $c$ & 0 & $c$ & 0 & c & 0 & $C$ & 0 & $C$ & 0 \\
\hline $\begin{array}{l}\text { Basal } \\
\text { Iso } 2\end{array}$ & $\begin{array}{r}245 \\
1097\end{array}$ & $\begin{array}{l}123 \\
609\end{array}$ & $\begin{array}{r}520 \\
2614\end{array}$ & $\begin{array}{r}487 \\
1837 c\end{array}$ & $\begin{array}{l}2.9 \mathrm{a \theta} \\
2.5\end{array}$ & $\begin{array}{l}4.7 \mathrm{bg} \\
3.1\end{array}$ & $\begin{array}{r}70 \\
1010\end{array}$ & $\begin{array}{r}63 \\
875\end{array}$ & $\begin{array}{r}455 \\
3036\end{array}$ & $\begin{array}{c}450 \\
2714 d\end{array}$ & $\begin{array}{l}6.2 f \\
2.9\end{array}$ & $\begin{array}{l}9.3 \mathrm{~h} \\
3.1\end{array}$ \\
\hline
\end{tabular}

${ }^{1} \mathrm{nmol} / \mathrm{h} / 10^{6}$ adipocytes, 6 cows/group $\left(\mathrm{C}=\right.$ control, $\mathrm{O}=$ oil). ${ }^{2}$ Isoproterenol, $4 \times 10^{-5} \mathrm{M}$. (ab) $(\mathrm{cd})(\mathrm{ef})(\mathrm{gh})=$ values within each pair differ $(P<0.1)$. 